\title{
LEGISLATION: PRIMARY, SECONDARY AND TERTIARY
}

\author{
John Burrows*
}

This article considers the question of the delegation of lawmaking. The increasing use of tertiary legislation in New Zealand is analysed. It is suggested that the use of tertiary legislation is concerning in some aspects including the potential for abuses of power, inaccessibility, complexity and inconsistency.

\section{INTRODUCTION}

We live in a parliamentary democracy where our elected representatives make the law. No doubt Parliament does not always operate as smoothly as one would like, and no doubt there are criticisms one may make about the process. But when we compare it with alternative forms of government we realise how lucky we are.

I suppose the ideal would be if Parliament made all our law itself (leaving I suppose a little common law to the judges). But that of course is, and has for a long time been, impossible. Too much needs to be done, so Parliament needs to delegate some of its lawmaking power. Indeed in this country from the mid 19th century there were Acts delegating to the Governor-General in Council power to make regulations. The output of regulations grew apace, and in the second quarter of the 20th century concerns were expressed in this country as well as elsewhere that there was too much of it, and it was not sufficiently controlled. In 1929 the Lord Chief Justice of England, Lord Hewart, wrote a book called "The New Despotism"1 in which he described the making of regulations by the executive as "a persistent and well contrived system intended to produce, and in practice producing, a despotic power which places Government departments above the sovereignty of Parliament". No doubt his Lordship was overstating the case, but his point had some validity. In New Zealand similar concerns were expressed by the New Zealand Law Society and others. These concerns bore fruit. From the mid 20th century onwards we witnessed the imposition of increasing checks and balances on regulation making.

* Formerly Professor of Law at the University of Canterbury; currently a Law Commissioner. This essay is a modified version of a lecture given at The Treasury, Wellington, on 26 May 2009.

1 Lord Hewart of Bury The New Depotism (Ernest Benn, London, 1929). 


\section{THE ACT-REGULATION DIVIDE}

A first question has received increasing attention of late. It is the question of what it is appropriate to delegate. In other words, what matters should be in the Act, and what in regulations? Generally it is said that the Act should contain the principles and the regulations the minor detail. In very general terms that is accurate enough. The Act sets up the framework of principle, while the regulations flesh out those principles with detailed machinery - the fees to be charged, the forms to be filled in, the procedures to be followed, and so on. But while it serves as a rough guide, this principle-detail distinction can be difficult to apply in practice. For one thing there is often no clear line between principle and detail: it is often more a matter of shades of grey. Moreover, some quite fine detail can affect people in a material way. Sometimes there is devil in the detail. In 2006 I was fortunate enough to be invited to the Parliamentary Counsel Office to facilitate a seminar in an attempt to formulate some guidelines on this difficult topic. Some guidelines did indeed emerge, ${ }^{2}$ although we recognised that they were very far from being the full answer.

What is so important that it should be done directly by Parliament rather than being delegated? To answer this we must keep in mind the features of our parliamentary lawmaking. They are the following. Our elected representatives make the decisions personally. They do so in the context of open debate, where different shades of political opinion can be expressed. The public can have their say through our system of select committees. All arguments for and against the proposal are recorded for posterity in explanatory notes to bills, regulatory impact statements, Hansard debates and select committee commentaries. There are Bill of Rights vets. Moreover, the process is usually slow and deliberate, which means that a proposal can take time to be enacted and once enacted can be difficult to change. (I have become very aware in Wellington of the, at times, unreasonable urgency with which proposals are required to be prepared and bills drafted. But once in the House the passage may take months, even years).

So the question is: what sorts of matters ought to be subjected to that democratic process? Here is a list of things which should go in the Act, although please do not treat it as an exhaustive one:

- $\quad$ Policy which affects citizens in a significant way;

- Policy which is controversial in that there are sharply divided opinions in society;

- Policy which affects human rights and freedoms (for example proposals for search and surveillance, or the taking away of property);

- The creation of offences, particularly ones enforceable by severe penalties;

- $\quad$ The imposition of tax;

2 Legislation Advisory Committee Guidelines on Process and Content of Legislation (2001), as updated in 2007, at ch 10 . 
- $\quad$ Provisions setting up a new agency or entity and the conferment of powers on it;

- Provisions conferring social and economic rights on which citizens will rely.

A further word about the last of these items. It is essentially about citizens' reliance. I believe, for instance, that social welfare legislation should locate essential criteria for the grant of benefits in the Act, so that people can be confident they will not be changed overnight by regulation. It is a matter of some interest that the Holidays Act 2003, which is regarded by employees as embodying one of their most important employment rights, is a very detailed Act which contains even such minutiae as the keeping of leave books by employers.

Nevertheless, even with that guidance there are often difficult calls to be made. It will never be possible to draw bright lines. Things which may weight the balance towards regulations include the following. First, if the legislation is technical and specialist regulations may often be appropriate. For example, Parliament would not have the expertise to scrutinise the content of such matters as civil aviation rules. Secondly, if the legislation is to be long and complex then there is sometimes a stronger case for putting it into regulations to avoid clutter which obscures the Act's main message. Thirdly, if content may need to be changed quickly, or on an ongoing basis, there may again be a case for allowing this to be done by regulation to avoid Parliament's more cumbersome process. So, for example, the Misuse of Drugs Act 1975 lists controlled drugs in a schedule, but there is power to add to this by regulation because it may sometimes need to be done as a matter of urgency.

I note a recent tendency, which I am not quite so sure about, for the main Act to list a set of criteria for making a certain decision and then to add at the end of the list "such other matters as may be prescribed by regulation". Whether this is to provide for circumstances changing over time, or to provide for things which may have been forgotten in the first place, I am never quite sure.

Sometimes history and tradition play their part as well. It has long been recognised that New Zealand's external relations is a matter in which the Executive Government properly takes an interest. It is not uncommon for Acts dealing with such matters (for example immigration and overseas investment) to leave large areas for regulation-making or other forms of executive decision making.

Even after all this, however, marginal calls continue to have to be made. We can all think of cases where we have wondered whether something which appears in the regulations should not really have been in the Act. There are others where we puzzle as to why the particular decision was made as it was. Here are two examples.

First, the Transport Rules ("the Rules"), which are of course delegated legislation, contain some of the most important legal rules in our community. We must abide by them every day. The rule that we must drive on the left hand side of the road is part of the Rules. However the rule that I must tie a load on a trailer securely was enacted by Parliament in s 9 of the Land Transport Act 1998. I have no idea why. Then, in our corrections legislation the rules about treatment of prisoners are oddly 
divided between Act and regulations. The rule confining the use of batons by prison wardens is in reg 123 the Corrections Regulations 2005. Yet the rule that a prisoner's bedding must be laundered regularly is in s 71 of the Corrections Act 2005. I cannot explain that distinction either.

\section{THE CONTROLS ON REGULATIONS}

Since mid 20th century we have developed a number of controls on regulation making. I am speaking here of traditional regulations - that is to say those made by the Governor-General in Council. Here is a list of the controls as they currently exist.

- Detailed empowering provision

- Parliamentary oversight (possible disallowance, and Scrutiny by Regulations Review Committee (RRC)

- $\quad$ Drafted by Parliamentary Counsel Office (PCO)

- $\quad$ Published in Statutory Regulations (SR) series Delegation, not abdication

- 28-day rule

- Cabinet scrutiny

- Regulatory impact statement

The first two of these confirm that when Parliament delegates its lawmaking powers it is a true delegation and not an abdication nor a relinquishment of those powers. Parliament should clearly define and delimit what it is that is being delegated, and it should retain control over the final product. The delegated lawmaker makes law on Parliament's behalf, and Parliament should retain the final say. I expand briefly:

First, until the mid 20th century, empowering provisions in some Acts were extremely wide and general, none more so than that in s 11 of the the Economic Stabilisation Act 1948, which provided that the Governor-General in Council could make regulations "to promote the economic stability of New Zealand". A government could do almost anything under that power. In 1961 a committee chaired by Sir Ronald Algie, the then Speaker of the House, recommended that in future empowering provisions Acts of Parliament should spell out clearly, and in reasonable detail, the purposes for which regulations could be made. That has been adhered to with reasonable consistency ever since, and many regulation-making powers in Acts have many paragraphs. An example is that in s 402 of the Building Act 2004. The Governor-General is empowered to make regulations for no less than 29 purposes, including the following:

(k) prescribing the form or content of applications, or any other documentation or information required under this Act: 
(m) prescribing time limits for the purposes of this Act:

(p) defining moderate earthquake for the purposes of sections 122 and 153:

And so on. No doubt if the list is long enough, depending a little on the phraseology of its parts, regulations can still cover quite a lot of ground. But at least there is clarity as to their permissible limits.

The second control in the list above ensures that Parliament is in control of the final product. Traditional regulations are subject to the Regulations (Disallowance) Act 1989, and to the jurisdiction of Parliament's Regulations Review Committee. That Committee can report to Parliament on regulations which make improper use of a delegated power, and under the 1989 Act Parliament could in fact disallow a regulation if it wished. That hardly ever happens, but the mere presence of the power and the activities and reports of the Regulations Review Committee have had a most beneficial effect.

The next three controls have to do with access:

The third is that regulations are drafted by the PCO. That office drafts both our Acts of Parliament and our regulations. The PCO are not only wordsmiths, although they are certainly that, they draft with a precision and clarity born of long experience. They are also experts on our law and constitution, and can and do advise on the best way of presenting legislation, on any difficulties it may pose for fundamental principle and on its relationship to the rest of our legislation. They are often called "the guardians of the statute book".

Fourthly, regulations must be published by the PCO. They are published in a numbered annual series, and appear in the red-backed set of volumes we call the SR series. They are thus readily accessible. We can go straight to them on the library shelves, and know exactly where to find the one we want. Regulations are also now published electronically on the New Zealand legislation website.

Fifthly, regulations are subject to what is known as the "28-day rule", that is to say a requirement that they will not come into force until 28 days after their making, to give those who will be subject to them an opportunity to become familiar with them.

Sixthly, regulations pass through Cabinet on their way to the Executive Council, and the opportunity is there for Ministers to comment on the regulations before they are finally made.

Seventhly, regulations are in all but exceptional cases accompanied by a regulatory impact statement. ${ }^{3}$

3 See Department of the Prime Minister and Cabinet "Guide to Cabinet and Cabinet Committee Processes" CabGuide <cabguide.cabinetoffice.govt.nz>; The Treasury Guidelines on the Regulatory Impact Analysis Requirements (November 2008). 
So I think we can say with reasonable confidence that a respectable set of controls and checks and balances has been built up around traditional regulations to make sure that the delegated lawmaker (effectively the executive) does not abuse its powers, and that the resulting regulations are accessible to those who are affected by them.

A bill currently before Parliament, the Legislation Bill 2010, is going to change some aspects of this, mainly but not entirely in the realm of terminology. Instead of regulations we shall have "legislative orders" and "disallowable instruments". But the substance of the protections I have described will not change.

\section{TERTIARY LEGISLATION}

However in the last 20 years or so there has been a new kid on the legislative block. It made occasional appearances before that time, but there has been a burgeoning increase in its incidence since 1990 or thereabouts. Acts of Parliament now not infrequently delegate lawmaking power to somebody other than the Governor-General in Council. It might be a Minister, for example, or an official or an agency. The product is not "regulations". There may be several reasons for doing it this way. Sometimes, I am sure, it is the belief that some agency other than the Governor-General in Council is more appropriate and more knowledgeable about the subject matter. I wonder, though, whether at other times it may simply be that the traditional regulation-making process is seen as being more cumbersome than necessary.

If this kind of delegated lawmaking is not "regulation", what is it? It is in some ways unfortunate that the name "tertiary legislation" has become attached it. The word "tertiary" might seem to suggest that this type of lawmaking is a level below regulation-making, in other words that it is a kind of sub-delegation. In fact, that is not so. It is still a direct delegation from Parliament, on the same level as regulations. The only difference is that the delegate lawmaker is different. The following diagram shows what I mean:

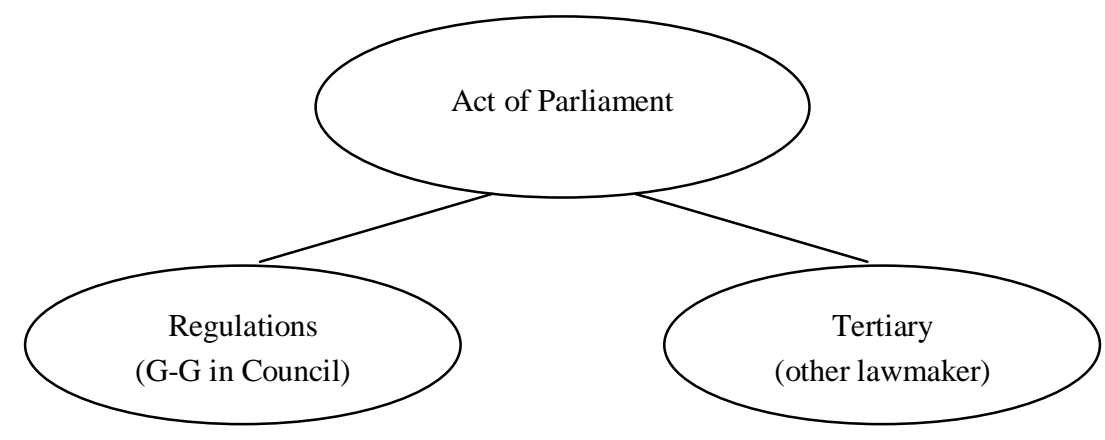


So who might the delegated lawmaker be? Sometimes it is a Minister, as for example in the Transport Rules. (If it is a Minister there is rather more protection than in the other cases, because rules made by a Minister are deemed to be regulations for many purposes) ${ }^{4}$ However at other times the delegated lawmaker may be an official or agency. For example, the Privacy Commissioner can make Privacy Codes; the Broadcasting Standards Authority can make Codes of Broadcasting Practice; the Legal Services Agency can make instructions for legal aid committees. Sometimes it is a regulator such as the Commerce Commission, Environmental Risk Management Agency (ERMA, under the Hazardous Substances and New Organisms Act 1996), or the new Real Estate Agents Authority. At other times it may be a professional body such as the Council of the Law Society or the Council of the Institute of Chartered Accountants. We can include in this last class universities and other tertiary institutions which also have power to make their own rules.

Under some of the more recent Acts rules made by such a delegate lawmaker need to be approved by a Minister before they are issued, ${ }^{5}$ but that is far from universal or even common.

The output of these various bodies is undoubtedly delegated legislation. It is made under authority of Parliament, and it lays down rules.

I would like now to ask several questions and make several comments about this relatively modern trend.

\section{A When is Tertiary Legislation Used Rather than Traditional Regulations?}

The Regulations Review Committee has taken the approach that regulations are the preferred form of delegated legislation, and tertiary legislation should only be resorted to in special circumstances. ${ }^{6}$ There is however a very large amount of tertiary legislation.

Sometimes it may be perfectly appropriate to resort to a tertiary lawmaker for reasons of independence. There are cases where it is desirable that the lawmaker be an independent agency, free from governmental or political influence. That is classically so in the case of the Broadcasting Standards Authority, which lays down standards for broadcasters. Freedom of the media is an important democratic principle, and it would not be appropriate for there to be political direction about the standards which broadcasters are to observe. Academic freedom is important in universities so, again, such bodies should be able to make rules for their own institutions free from

4 See the definition of "regulations" in the Regulations (Disallowance) Act 1989, s 2, the Acts and Regulations Publication Act 1989, s 2 and the Interpretation Act 1999, s 29.

5 See the practice rules made under the Lawyers and Conveyancers Act 2006, s 100.

6 See Regulations Review Committee Inquiry into instruments deemed to be regulations - An examination of delegated legislation (1999). See also the Guidelines on Process and Content of Legislation, above n 2, at ch 10.4 as amended in 2003. 
political interference. I have heard it argued that what universities make is not really law at all, but rather just rules internal to their own organisations, rather like the rules of a club. In fact it is much more than that. Universities are empowered to make their rules by an Act of Parliament, and those rules can affect people outside their institutions: most universities for example have made admission rules which can affect the rights of people to enter the institution.

Another situation where it may be appropriate to resort to a tertiary lawmaker is where the subject matter is so technical it is best left to an expert. I have previously mentioned the scientific specialism of ERMA, and our civil aviation rules. There would be little point in their going to Cabinet. In any event, their audience is only a small and specialist sector of the general population.

However, most of our tertiary legislation does not emanate from bodies of this kind. Most of it is a feature of business regulation. In the 1980s the state withdrew from the provision of many services. The door was opened up to competition. There was what was (somewhat paradoxically) called "deregulation". Yet the state obviously felt that regulation was required to protect the public from the worst excesses of this free market. There was of course some regulation in earlier times, but there has been an increased flow of legislation since the 1980s setting up agencies to regulate various industries and professions, and to make rules for their proper conduct. There are many different models. In some, the regulation is very light-handed, and amounts to a kind of statutorilymandated self-regulation. A good example of that is the Institute of Chartered Accountants of New Zealand Act 1996 where the empowering Act of Parliament does little more than set up the Institute, give it power to make rules, and authorise it to set up a disciplinary tribunal to enforce those rules. It effectively says to the Institute: "make your own rules and enforce them".

At the other end of the scale, however, some Acts have set up new agencies (some of them being crown entities) or deployed existing agencies to oversee certain industries, to make rules for those industries, and to enforce them. Some of the regulation is quite heavy handed. Recently we saw the enactment of the Real Estate Agents Act $2008^{7}$ setting up a Real Estate Agents Authority with such powers. The Insurance (Prudential Supervision) Act 2010 gives the Reserve Bank regulatory powers in relation to insurance companies. Legislation like this continues apace.

Again some people argue that rules made by such bodies are not really law at all: that they are simply rules to regulate a closed community or a particular profession or industry. But these bodies do make law. They are authorised by an Act of Parliament which delegates power to the relevant agency. The rules made by the agency affect a class of the population; they affect the rights and duties of that class. Moreover the general public have an interest, because the rules are often for their protection. Rules made by such bodies are often called "statutory instruments" or "legislative

7 Most of its provisions came into force 14 months after its enactment 
instruments". The New Zealand Cabinet Office in a circular in 2008 defines that term in a useful way. It says that a legislative instrument is one which: ${ }^{8}$

1) regulates the public generally or any class of the public (including an occupational class) and

2) prescribes or imposes obligations, confers entitlements, or creates benefits or privileges.

In other words the rules made by the regulator affect the legal rights of individuals. Very similar statutory definitions appear in Australia, where some jurisdictions have passed Acts of Parliament detailing the requirements of such statutory or legislative instruments.

\section{$B$ What are the Controls and Checks and Balances on Tertiary Legislation?}

I have shown earlier in this paper the trouble our legal system has gone to develop controls, or checks and balances, on traditional regulations. These checks and balances apply automatically only to traditional regulations. Thus, the Regulations (Disallowance) Act 1989 and the Acts and Regulations Publication Act 1989 are expressly confined to regulations. ${ }^{9}$ There is no automatic application of any of these same checks and balances to tertiary legislation. If there are to be checks and balances on this, they must be created by each individual Act which empowers such lawmaking.

Some of the empowering provisions of the statutes are quite wide. They are by no means all the same, and I may be being unfair by picking one example, but here is the rule making power in $\mathrm{s} 14$ of the Real Estate Agents Act 2008.

14 Code of professional conduct and client care

(1) The Authority may, by notice in the Gazette, make any practice rules to enable it to discharge the duty imposed on it by subsection (2).

(2) The Authority must have rules that include or provide for a code of professional conduct and client care, which will be a reference point for discipline and which will focus on, but need not be limited to, the duties of agents to their clients.

That gives a power of some breadth.

Unless the individual empowering Act says so, the normal controls on traditional regulations will not apply. So, the tertiary legislation will not be subject to the jurisdiction of the Regulations Review Committee; it will not be subject to disallowance in Parliament; it will not be drafted by the

8 Cabinet Office Circular "Delegated Legislation: Guidelines for Legislative Instruments that are not Regulations" (14 March 2008) CO 08/4 at [5.1-5.2]. Compare the definitions in the Statutory Instruments Act 1992 (Qld), s 7 to the Legislative Instruments Act 2003 (Cth), s 5.

9 Rules made by a Minister are included, however. 
PCO (some of it is not very well drafted at all); it will not be published in the SR series; it will not go to Cabinet, and so on. So what controls are there? There are only those which appear in each empowering statute. But here are some of the controls we are beginning to see with reasonable frequency:

First, a number of the empowering Acts require consultation with affected interests before the various rules are made. Of course, consultation is an important and necessary tool, but it will only ever be targeted consultation as opposed to the general invitation to the public which happens when a Bill is before a Select Committee in Parliament. Of course consultation will not always ensure that the best decisions are made. How could it?

Secondly, as I mentioned earlier, in some of the modern Acts there is a requirement that before the rules made by the delegated lawmaker can be issued they must be approved by the relevant Minister. The Minister does not make them; he or she approves them. But this does at least mean that more eyes will look at the document before it is signed off by the Minister.

Thirdly and most importantly, some Acts declare rules made under them to be regulations for the purposes of the Regulations (Disallowance) Act 1989. They are then called "deemed regulations". I am pleased to say that this is happening increasingly often. A Cabinet circular in 2008 said that it should happen whenever the "Executive" is the lawmaker. ${ }^{10}$ It is in fact happening even more often than that. It means that the delegated legislation when made can be disallowed by Parliament, and it also means that it comes within the jurisdiction of the Regulations Review Committee. However this "deemed regulation" device is by no means universal. There is a great deal of tertiary legislation out there which is not in this category.

Finally, most modern empowering acts do provide for some form of publication of the tertiary legislation. Some are "deemed" to be regulations for the purposes of the Acts and Regulations Publication Act 1989, but that is not particularly common. ${ }^{11}$ A more usual provision is that the making of the rules must be notified in the Gazette, and that there should be notification of where the rules can be inspected, and where copies may be purchased. In some cases there is even a requirement that the agency responsible for the rules must publish them on its website.

But there can be difficulties of access even then. Some tertiary legislation (and even some regulations come to that) incorporates other documents by reference; in some of those other documents there may be copyright. It is so, for example, of standards made by the New Zealand

10 Cabinet Office Circular, above n 8, at [17]. But see also ibid, at [12.1] where it is acknowledged that subjection to disallowance may not be appropriate where "the instrument is made by an industry or independent body and is not subject to ministerial approval."

11 See ibid, at [15] which states that "all legislative instruments that are subject to disallowance should also be subject to the Acts and Regulations Publications Act 1989", although it allows for exceptions where, for example, the instrument contains technical matter or is impracticable for reasons such as size or complexity. 
Standards Council. ${ }^{12}$ Such incorporated material cannot be published free of charge on the internet because of the copyright issue. But there is an even more significant difficulty. There is no index of tertiary legislation. The PCO has performed a signal service in providing on its website a list of all deemed regulations (there are over 400 of them). But this list only contains deemed regulations for the purpose of the Regulations (Disallowance) Act 1989, not the many other sorts of tertiary legislation. For those, there is no available list or index at all. To track them all down one needs to look at all the empowering Acts of Parliament, and check on the websites of the various agencies. That would take a very long time.

So, then, there is increasing recognition of the problems. The Regulations Review Committee, the Cabinet Office and the Legislation Advisory Committee have increasingly drawn attention to the need to provide appropriate checks and balances in tertiary legislation. There is still a lot of it about where the checks and balances are very much less than those which are in place for regulations. It may seem at times as though the controls so deliberately developed for regulations have been circumvented too readily.

\section{A Confusion of Names}

The tertiary legislation made under these delegated powers goes by a confusing array of names. Here are some of them, derived from a fairly quick survey of some of the most recent Acts of Parliament.

- Code

- Compliance Document

- Control

- Directions

- Framework

- Guidelines

- Instructions

- Instruments

- Notice

- Mechanism

- Policy

- Programme

- Rules

- Standards

- Strategy

12 Under the Standards Act 1988. A Bill to replace this Act is before Parliament: see the Standards and Accreditation Bill 2008 (292-1). 
Sometimes the names are even more specialised. Under recent amendments the Commerce Commission has power to issue "input methodologies", "price quality paths" and "thresholds for control". Under the Trade (Safeguard Measures) Bill ${ }^{13}$ currently before Parliament the Minister may impose a "safeguard measure". (I have left out of contention specific exemptions and directives given to individual persons or organisations, because they do not affect a class of the public as such. I also do not deal in this paper with by-laws. They are a separate study altogether). Perhaps some feel that the huge variety of names is not problematic. After all what's in a name? But I think it is not so straightforward.

First, we do tend to assume that where a name is different then the substance is different also. In ordinary language as well as legal language difference of name usually indicates difference of kind. But in the above list it is far from clear that that is always the case. Is there really any difference between "instructions" and "directives", or between "rules" and "codes of practice"?

Secondly, language is a powerful tool. What something is called can affect our perception of it, and how we react to it. If what is issued by a regulator is called "instructions" it can cause a reaction different from something which is called a "code of practice". Yet on closer study of particular instances there may be no difference at all between the legal effects of the two different sorts of document. It is also a little worrisome to reflect that such difference in terminology may also affect the behaviour of enforcers, let alone that of those subject to the rules.

Finally, such is the variety of terminology are we not entitled to say that the law is becoming more complex than it needs to be? And is complexity in our legal system not the last thing we should be striving for?

\section{A Confusion of Legal Effects}

Delegated legislation has the effect which is given to it by the empowering Act, no more and no less. When we look at the various Acts, and there are many of them, we find that they give the various forms of tertiary legislation a very large number of possible effects. Sometimes instruments with the same name have different legal consequences under different Acts. Here are some in descending order of severity.

- Non-compliance is an offence;

- $\quad$ Non-compliance may be made an offence by regulation;

- Non-compliance may lead to disciplinary action;

- Non-compliance is subject to a complaints process;

- A Code is enforceable as a contract;

- Compliance is a defence;

- $\quad$ Rules may be "taken into account";

13 Trade (Safeguard Measures) Bill 2008 (294-2). 
- Non-compliance renders some kinds of action ineffective;

- A Code (or other set of rules) is evidence of good practice;

- $\quad$ No clear effect is spelt out at all;

- The document simply contains advice.

Allow me to comment on this.

First, some of the Acts empowering tertiary legislation are long and quite complex in themselves. It sometimes requires lengthy study of the Act to find out exactly what effect tertiary legislation made under it is to have. For example the Animal Welfare Act 1999 provides for the making of animal welfare codes. Nine of them have already been made. Yet one has to read the Act quite closely to find out what effect the codes of welfare have once they have been made. Eventually one discovers that their effect is that if they are complied with that is a defence to a charge of ill-treating animals under the Act. In other words, compliance confers immunity.

Secondly, given this great variety of legal effect people subject to one of these instruments may sometimes assume that it has greater effect than the law actually gives it. A small business owner unable to afford expensive legal advice may assume that every code of practice, and every set of guidelines, emanating from a regulator has binding force. That person might even assume he or she will face a criminal penalty if there is failure to comply. No legal document should ever be perceived to have a force more severe than in fact it does have.

Thirdly, and even more seriously, it is not beyond the bounds of possibility that the regulators themselves might occasionally assume that the rules, guidelines, codes, or whatever, that they make have more force than they actually do, and that they, the regulators, have greater power than the Act actually gives them. Not all members of regulatory agencies are lawyers. Sometimes they may misunderstand the Act which sets them up, and which defines what they can and cannot do.

Finally, such a variety of instruments with such a variety of effects can in the end blur our very understanding of what law is. Legal rules are those which affect the rights and duties of members of the public or a class of the public. The cascade of types of instruments I outlined above contains at the top end some which lay down powerfully enforceable duties. But at the bottom end the instruments are simply guidelines and advice which do not affect anyone's legal rights. They are not in fact law at all. I would say that the bottom three in my list should not in fact be called statutory instruments at all. But they often are so called. Sometimes the expression "soft law" is used of them. "Soft law" is an expression which originated in international law, but is developing a certain currency in domestic law too. Most lawyers (at least in this country) resist the use of that term. A document either has legal effect or it does not, and the legal effect it has is determined by the Act under which it was made. I am concerned about the danger that documents may be thought to have a force which they simply do not possess. 
I would like to pause for a moment to ask how this variety of both name and legal effect has come about. Why do we not have more consistency? I think it is simply because the various Acts have had their origins in different departments, ministries and agencies. Each of these has developed considerable specialisation and is concerned to tailor what it sees as the best solution, sometimes a very innovative solution, to the particular circumstances. I have seen this phenomenon described as "hyper-innovation". ${ }^{14}$ In this complex modern world specialisation is inevitable and desirable. But it has its downsides. It can lead to the specialists not looking outside the four corners of their specialist box at what others are doing. And innovative solutions can sometimes be at odds with broader legal principle. When you see such a variety of solutions you must ask whether some of the ways of doing the job are not better than others, and whether some do not achieve a more desirable balance between protection of the public and the rights of those subject to the regulation. It does seem to me that in the subject of tertiary legislation there is room for a lot more consistency of principle.

\section{$E$ Volume, Length and Complexity}

Some modern Acts empower the making of a variety of tertiary legislation (or a variety of legislative instruments, if you prefer). One Act, ("Act A"), empowers the making of notices, codes of practice, controls, standards and group standards, in addition to traditional regulations. Another, ("Act B"), empowers the making of codes, rules, compliance documents, guidance information and traditional regulations. As I have pointed out, that variety can confuse the novice, and even the experienced practitioner. It leads to a pile of documents all having slightly different effects.

Volume and length are a problem as well. There is a much greater output of legislation now than there used to be. The length of individual documents has greatly increased. The following figures are quite revealing:

\begin{tabular}{|c|c|c|c|c|}
\hline Year & $\begin{array}{c}\text { Population of } \\
\text { NZ }\end{array}$ & Acts passed & Regulations & $\begin{array}{c}\text { Tertiary } \\
\text { Legislation }\end{array}$ \\
\hline 1960 & $2.4 \mathrm{~m}$ & 123 Act & 198 Regulations & Very little \\
720 pages & 944 pages & \\
\hline 2008 & $4.3 \mathrm{~m}$ & 111 Acts & 456 Regulations & $\begin{array}{c}\text { Not readily } \\
\text { discoverable }\end{array}$ \\
\hline
\end{tabular}

They show that in 2008 there were less Acts of Parliament than in 1960 (in the 1980s the number of Acts was greater than this, sometimes exceeding 200 a year, but MMP has pulled the number back). Nevertheless what is very clear is that the total number of pages, and thus the length of individual Acts, has increased greatly. As far as traditional regulations are concerned not only has

14 Chris Berg "Regulation and the regulatory burden" (2008) Goliath Business Knowledge on Demand <goliath.ecnext.com>. 
the number increased by more than double, but the average page numbers have increased by pretty much double as well. In 1960 there would have been very little tertiary legislation indeed. In 2008 I fear I do not know how much there was; it would take a while to find out.

Individual legislative instruments, including Acts of Parliament, have increased considerably in length over the years. Look at these comparisons:

\begin{tabular}{|l|l|}
\hline \multicolumn{1}{|c|}{ Act } & \multicolumn{1}{c|}{ Number of Pages } \\
\hline State Supply of Electrical Energy Act 1917 & 4 pages \\
Electric - Power Boards Act 1925 & 36 pages \\
Electricity Act 1945 & 36 pages \\
Electricity Act 1992 & 179 pages \\
\hline Health Act 1956 & 89 pages \\
Public Health Bill 2007 & 259 pages \\
Food Act 1981 & 113 pages \\
Food Bill 2010 & 342 pages \\
\hline
\end{tabular}

That increase is even more remarkable when one considers changes in drafting style. Drafting styles are much more economical these days than they used to be. Long sentences and repetition are discouraged. The fact that Acts are much longer than their forbears is because more things apparently need to be regulated and provided for. Sometimes I suppose that may be necessary. There is concern, perhaps, that unless every detail is tied down and every gap closed there will be too much "wriggle room". The Electricity Act 1992 is over five times the length of its predecessor (and the 1992 Act is accompanied by 280 pages of regulations and hundreds of pages of rules). ${ }^{15}$ The Public Health Bill ${ }^{16}$ is three times the size of the Health Act 1956. It would be an interesting exercise to work through such legislation, and find out exactly what has been added and how necessary that added material is.

Long documents, necessary though they apparently are in some cases, can be problematic.

15 See also the Electricity Act 1968 which was accompanied by 170 pages of regulations - bad enough in itself.

16 Public Health Bill 2007 (177-2). 
First, people affected by the law find knowing their rights increasingly difficult. They increasingly need legal advice to pick their way through long and complex legislation.

Secondly, the longer a document is the less chance it will be properly understood, even by experts. In our busy lives we do not have as much time as we need to pore over and carefully analyse documents. We tend to take parts of them out of context, increasing the risk that those bits will be misunderstood.

Thirdly, some areas have become so complex that regulators find it necessary to provide summaries for the people subject to them, with the accompanying risk that such summaries may take less, or (even more worrying) more, than the full story. That, in a sense, gives even more power to the regulators, because the summary is all some people will read.

The comparative merits of broad principle and minute detail is an issue in many areas of law. I wonder if at times we are not going into more detail than we need?

\section{CONCLUSION}

Let me sum up some concerns. First, the makers of legislation need to be mindful of possible abuses of power. They should ensure that the checks and balances are right. Concerns have recently been expressed that even the checks and balances on Parliament's law-making processes are not as good as they should be. The concerns are far greater with delegated legislation, and with tertiary legislation more than regulations. Let us not forget the ideals of parliamentary democracy mentioned at the beginning of this article.

Secondly, it is so important that law be accessible to those who are subject to it. Accessibility is very far from perfect in some areas of our law. Some tertiary legislation is not easy to find. Some of it is not as well drafted as it should be. The volume and complexity which I have written about can be a problem. Simplicity is a wonderful virtue. Has our society really become so complicated as a result of technology and other developments that simplicity is no longer possible? Might clear principle not sometimes be more effective than turgid detail?

Thirdly, the variety and inconsistency manifest in some of our statutory instruments is the enemy of principle.

Finally, there is a point I have not yet touched upon. Are we sure that all this law, and all this regulation, actually works? I often feel that in New Zealand we regard lawmaking as an end in itself. Yet words on a piece of paper are not an end in themselves. We need to be able to demonstrate that they have the effect that was desired at the time they were made; in other words, that they have fulfilled their purpose. We do not do as much post-legislative scrutiny as we should. What is needed, I think, is an extensive study to discover exactly whether all of this legislation, in particular all of this tertiary legislation, has really cured the problems it was set out to cure. Australia has introduced a system of sun-setting regulations to force periodic review of them. It will be fascinating to see how that system works. There have been moves to introduce it here. I can 
understand there might be resistance, because it will involve a lot of work. But it might well begin to make our legal system a better and less confusing place.

In the meantime, as long as we have our current system, lawmakers need to ask a number of important questions before they recommend any new legislation at whatever level. The Legislation Advisory Committee, the Cabinet Office and the Regulations Review Committee regularly reassert these questions. There is no harm in setting them out again. Before any exercise in lawmaking we should ask:

- Do we actually need this piece of legislation? That is the most important question of all.

- If we do, why have we chosen to do it this way? For example, might it be better in regulations rather than in tertiary legislation?

- What checks and balances are there, and what controls on possible abuse of power?

- How is the legislation to be made known to those who are affected by it?

- Is it as simple as it can possibly be? Do we really need such a volume of detail?

- $\quad$ Are we sure it is going to work? 
(2011) 42 VUWLR 